\title{
Sirenomeli
}

\section{Sirenomelia: Case Report}

\section{Selçuk YETKINEL, ${ }^{a}$ \\ Tayfun ÇOK, ${ }^{\mathrm{a}}$ \\ Hakan KALAYCI, ${ }^{a}$ \\ Halis ÖZDEMIR, ${ }^{a}$ \\ Pınar ÇAĞLAR AYTAÇ, ${ }^{\circ}$ \\ Ebru TARIM, ${ }^{a}$ \\ Bermal HASBAYb}

aKadın Hastalıkları ve Doğum AD,

Perinatoloji Bölümü,

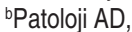

Başkent Üniversitesi

Adana Uygulama ve Araştırma Merkezi,

Adana

Geliş Tarihi/Received: 13.07 .2014

Kabul Tarihi/Accepted: 01.04.2015

Yazışma Adresi/Correspondence:

Hakan KALAYCI

Başkent Üniversitesi

Adana Uygulama ve Araştırma Merkezi,

Kadın Hastalıkları ve Doğum AD,

Perinatoloji Bölümü, Adana,

TÜRKIYE/TURKEY

smartdr96@yahoo.com
ÖZET Sirenomeli, alt ekstremitelerde füzyon, tek umbilikal arter, iskelet-kas anomalileri, ürogenital ve gastrointestinal sistem anomalileri ile karakterize, nadir görülen bir sendromdur. Bu malformatif bozukluğun en belirgin hâli, alt ekstremitelerin parsiyel veya total füzyon sonucu tek bir uzuv şeklinde izlenmesidir. Sonuçta, antik Yunan mitolojisindeki denizkızına benzer görünüm meydana gelmektedir. Bu çalışmada, kliniğimize ilk trimesterde başvuran ve tanısı konulan sirenomeli olgusu sunulmuştur. Otuz üç yaşında, yaşayan üç gebeliği ve yaşayan iki sağlıklı çocuğu bulunan gebe, 13 . gebelik haftasında polikliniğimize başvurdu. Ultrasonografide baş popo mesafesi $52 \mathrm{~mm}, 12 / 5 \mathrm{hafta}$ ile uyumlu ve fetal ense kalınlığ 1.95 mm olan fetüsün bilateral böbrekleri ve mesanesi izlenemedi. Tek umbilikal arter saptandı. Bilateral alt ekstremiteleri yapışık görünümde idi. Her iki femuru altta füzyone olmuş tek tibia ile devam ediyordu. Sirenomeli, ciddi renal anomaliler nedeni ile çoğunlukla yaşamla bağdaşmayan ölümcül bir anomalidir. Ultrasonografi ile erken tanı konulması, ebeveynlerin olası terminasyon kararı alması açısından büyük öneme sahip olacaktır.

Anahtar Kelimeler: Doğumsal anomaliler; erken tanı; Mermaid sendromu; prognoz; anormallikler, çoklu

\begin{abstract}
Sirenomelia is a relatively uncommon syndrome. Musculoskeletal disorders such as lower extremity fusion, urogenital and gastrointestinal system abnormalities could meet the criteria of this syndrome. By this article, a case of sirenomelia syndrome is presented. The most prominent yet inconstant feature of this malformative disorder is the complete or partial fusion of the lower limbs into a single lower limb. The resultant infant bears a resemblance to the mermaid of ancient Greek mythology. 33 year old woman whom has had two healthy and alive children from three preganancies was consulted to our perinatology clinic at 13 weeks of gestation. CRL measure of $52 \mathrm{~mm}$ corresponds to 12 weeks 5 days of gestation. Fetal nuchal translucency was 1,95 mm. Bilateral kidneys and bladder couldn't have seen by ultrasonography. Only one umblical artery has dedected. Bilateral femur bones has continued with fused tibial bones has observed. Because of accompained serious renal abnormalities, sirenomelia is a fatal syndrome. For this reason diagnosis time plays a substantial role in parents decision at pregnancy termination.
\end{abstract}

Key Words: Congenital abnormalities; early diagnosis; Mermaid syndrome; prognosis; abnormalities, multiple

Turkiye Klinikleri J Gynecol Obst 2015;25(3):217-20

irenomeli, alt ekstremitelerde füzyon, tek umbilikal arter, iskeletkas anomalileri, ürogenital ve gastrointestinal sistem anomalileri ile karakterize, nadir görülen bir sendromdur. 1/60.000-1/100.000 doğumda görülmektedir. Eşlik eden anomaliler, ki bunların başında gelen renal anomaliler çoğunlukla ölümcül seyretmekte ve kayıplar yenidoğan 
döneminde olmaktadır. Monozigotik ikiz gebeliklerde ve erkek fetüslerde daha sık izlenmektedir. Posterior kaudal blastem gelişimindeki ciddi defektler sonucu oluştuğu düşünülmektedir. ${ }^{1}$ Alt ekstremitelerdeki füzyon sonucu fetüslerde Yunan mitolojisinde bahsi geçen denizkızı görüntüsü oluşmaktadır. Fetüslerde literatürde alobar holoprosensefali, lumbar meningomiyelosel ile birlikteliği olan olgular da bildirilmiştir. ${ }^{2}$

Bu çalışmada, kliniğimize ilk trimesterde başvuran ve tanısı konulan sirenomeli olgusu sunulmuştur.

\section{OLGU SUNUMU}

Üç gebeliği ve yaşayan sağlıklı iki çocuğu bulunan, eşler arasında akrabalık bulunmayan 33 yaşındaki gebe olgumuz, 13. gebelik haftasında polikliniğimize başvurdu. Hikâyesinde kronik hastalığ ve sürekli kullandığı ilaç bulunmamakta idi. Ayrıca, aile hikâyesinde ne anne ne de babada ek konjenital anomali bilgisine rastlanmadi.

Fetüsün ultrasonografi (USG)'sinde baş popo mesafesi $52 \mathrm{~mm}, 12 / 5$ hafta ile uyumlu, fetal ense kalınlığı 1,95 mm idi. Kafa ve beyin yapıları haftasına göre normal görünümde idi. Bilateral üst ekstremiteler normal görünümde idi. Fetüsün bilateral böbreklerinin ve mesanesi izlenemedi. Tek umbilikal arter saptandı. Bilateral alt ekstremiteleri yap1şık görünümde idi. Her iki femur kemikleri altta füzyone olmuş tek tibial kemik ile devam ediyordu (Resim 1). Tüm USG bulguları sirenomeli tanısını destelemekte idi.

Fetüsün doğum sonrası yaşam süresi ve yaşam kalitesi ile ilgili bilgiler aile ile paylaşıldı. Ailenin isteği ve onayı ile $30 \mathrm{~g}$ ağırlığındaki cinsiyeti belirlenemeyen fetüs termine ettirildi (Resim 2). Terminasyon sonrası çekilen direkt grafi görüntüsü prenatal USG bulgularını desteklemekte idi (Resim $3)$.

Patoloji kliniğimizce uygulanan otopsi sonucunda, fetüste alt ekstremite füzyonu, düşük kulak, imperfore anüs, iç ve diş genital organ yokluğu, dismorfik böbrek dokusu, gastroşizis, sol ayakta oligodaktili gibi ek anomaliler de saptandı. Sirenomeli tanısı doğrulandı.

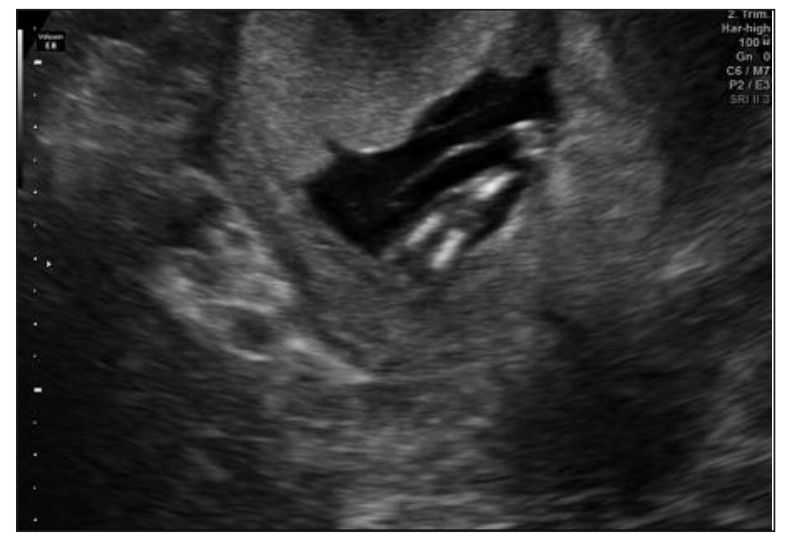

RESiM 1: Her iki femur ve altta füzyone olmuş tek tibia.

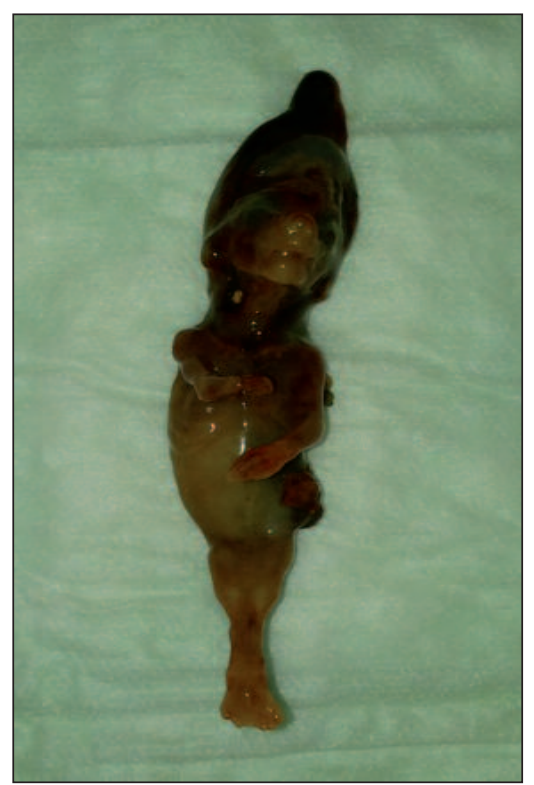

RESIM 2: Makroskobik olarak alt ekstremite total füzyon hâlinde izlendi.

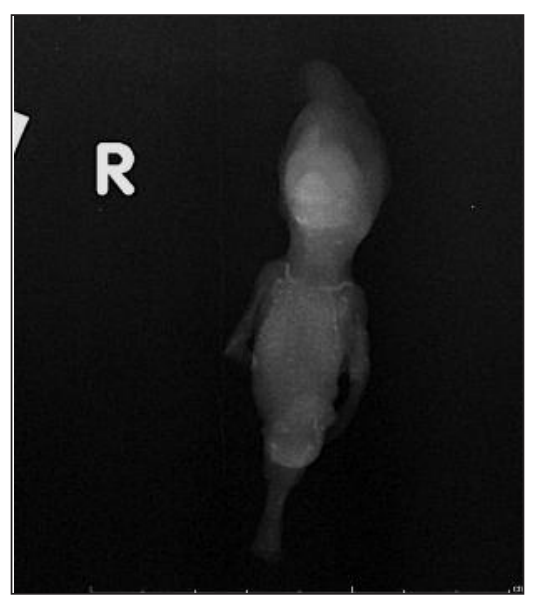

RESIM 3: Direkt grafide bilateral femurlar izlenmekte, tibia ise füzyone görünmekte. 


\section{TARTIŞMA}

Sirenomeli, alt ekstremitelerdeki defekt ve eşlik edebilecek ek anomaliler nedeni ile aile açısından çok sıkıntılı bir klinik antitedir. Risk faktörleri arasinda maternal diyabet, teratojenler ve genetik faktörler yer almaktadır. ${ }^{3}$ Sirenomelili fetüslerin \%22'si diyabetik anne bebeğidir. ${ }^{4,5}$ Hastalığın patogenezinde öne çıkan iki teori; vasküler çalma sendromu ve defektif blastogenez hipotezidir.

Normal fetüslerde iki umbilikal arter çölyak trunkustan dallanarak kanı plasentaya götürür. Vasküler çalma sendromuna göre defektif oluşan tek umbilikal arter, yani vitelin arter ise bilateral renal arterler dallanmadan önce direkt olarak aortadan çıkar. Böylece, kan akımının embriyonun kaudal kısmından plasentaya doğru yanlış yönlendirilmesine neden olur. Kan alt ekstremitelerden plasentaya doğru ilerler. Bu durum küçük bir aorta oluşumuna neden olur. Böylece böbreklerde, barsaklarda ve genital organlarda arteriyel akım kayıpları oluşur. Terminal barsaklar, böbrekler, mesane, genital organlar ve pelvik kemiklerde gelişim kusuru oluşur. Chikkannaiah ve ark., dört olguluk çalışmalarında, otopsi sonuçlarında anormal damarlanmaları göstermişlerdir. ${ }^{2}$

Normal umbilikal artere sahip sirenomeli olgularının bildirilmesi; kraniyal, vertebral, anal, kardiyovasküler, trakeal, özofageal defektlerin sadece vasküler teoriyle açıklanamaması; patogenezde defektif blastogenez hipotezini öne çıkarmıştır. Blastogenez, gebeliğin dördüncü haftasına kadar devam eden embriyonel gelişim periyodudur. Bu periyodda diferansiye olmamış hücreler spesifik morfolojik hücrelere dönüşür. Bu dönüşümdeki en küçük bir müdahale defektlere neden olur. Her iki hipotez diğerini anlamsız kılmasa da defektif blastogenez eş zamanlı organ defektlerini açıklamaktadır. Embriyogenez sırasında kaudal regresyon döneminde retinoik asit maruziyeti sonucu azalan "bone morphogenesis protein (BMP)" nedeni ile hayvan deneylerinde sirenomeli vakaları oluşturulmuştur. ${ }^{6}$

Tica ve ark., fenobarbital ve karbamazepin kullanan bir gebede sirenomeli olgusuna rastladıklarını bildirmişlerdir. ${ }^{3}$ Ağır metal maruziyeti ile si- renomeli arasında ilişki olduğunu gösteren yayınlar da mevcuttur. ${ }^{7,8}$

Sendrom özellikle \%15-20 oranında monozigotik ikiz gebelikler ile ilişkili bulunmuştur. ${ }^{9}$ Ancak, sunduğumuz olgu tekil bir gebelikti.

Stocker ve Heifetz, sirenomeliyi Tip I'den Tip VII' ye sınıflamışlardır. ${ }^{9}$ Tip I, en hafif formu, tüm kemikler füzyone olmuş iki bacakta mevcuttur ve füzyon sadece iki bacaktaki yüzeyel dokuları içermektedir. Tip VII'de ise tek kemikten başka bacak ve ayak yapıları izlenmez. Bu iki tip arası tiplendirmeler füzyon derecelerine göre sinıflanmaktadir.

USG prenatal tanıda en etkin yöntem olarak gözükmektedir. Ancak, eşlik eden renal anomaliler nedeni ile erken dönemde gelişebilecek anhidroamniyoz durumlarında tespit zorlaşabilir. ${ }^{10}$

Biyokimyasal olarak alfa feto protein yüksekliğine yol açacak fetal herhangi açık defekt bulunmamaktadır. ${ }^{11}$

Renal agenezi-disgenezi, obstrüktif renal yetmezlik gibi eşlik eden anomalilerin varlığında yaşamla bağdaşmayan bir klinik tablo oluşmaktadır. ${ }^{12}$ Günümüzde yaklaşık \%50 oranında yaşamın ilk sekiz-dokuz ayına kadar yaşamını devam ettiren infantlar bildirilmektedir. ${ }^{13}$ Ancak, çoğu infantın yaşamının ilk beş yılında kaybedildiği de bilinmektedir. ${ }^{9}$

Doğumdan sonra sirenomeli yönetimi aileler için pahalı, uzun ve sonu kestirilemeyen bir periyodu içermektedir. Tabii ki eşlik eden anomalilerin varlığı bu süreyi ve sonucu etkileyecektir.

Yaşayan sirenomeli olguları bildirilmektedir. Mesanesi olmayan ve dört yaşından önce art arda beş cerrahi operasyon geçirmiş olan, yatalak bir infant bildirilmiştir. ${ }^{14}$

Tüm bu gelişmeler ve sendromun doğumdan sonra aileye ve infanta yaşatabileceği maddimanevi zorluklar göz önüne alındığında, erken dönemde tanı konulmasının, durumun aile ile tartışılıp nihai bir karar verilmesinde etkisi tartışılmayacak kadar açıktır. Bu nedenle sendromun erken tanısı, olası terminasyon kararı ve anne sağllğı açısindan öneme sahip olacaktır. 


\section{KAYNAKLAR}

1. Singh C, Lodha P, Arora D, Prabhu Sharma A, Kaul A. Diagnosis of sirenomelia in the first trimester. J Clin Ultrasound 2014;42(6):355-9.

2. Chikkannaiah $P$, Mahadevan $A$, Gosavi M, Kangle R, Anuradha, Shankar SK. Sirenomelia with associated systemic anomalies: An autopsypathologic illustration of a series of four cases. Pathol Res Pract 2014;210(7):4449.

3. Tica OS, Tica AA, Brailoiu CG, Cernea N, Tica VI. Sirenomelia after phenobarbital and carbamazepine therapy in pregnancy. Birth Defects Res A Clin Mol Teratol 2013;97(6):4258.

4. Aslan H, Yanik H, Celikaslan N, Yildirim G, Ceylan Y. Prenatal diagnosis of caudal regression syndrome: A case report. BMC Pregnancy Childbirth 2001;1(1):8.

5. González-Quintero VH, Tolaymat L, Martin D, Romaguera RL, Rodríguez MM, Izeqiredo LA.
Sonographic diagnostic of caudal regression in the first trimester of pregnancy. J Ultrasound Med 2002;21(10):1175-8.

6. Garrido-Allepuz C, Haro E, González-Lamuño D, Martínez-Frías ML, Bertocchini F, Ros MA. A clinical and experimental overview of sirenomelia: insightinto the mechanisms of congenital limb malformations. Dis Model Mech 2011;4(3):289-99.

7. Castilla EE, Mastroiacovo P, López-Camelo JS, Saldarriaga W, Isaza C, Orioli IM. Sirenomelia and cyclopia cluster in Cali, Colombia. Am J Med Genet A 2008;146A(20):2626-36.

8. Orioli IM, Mastroiacovo P, López-Camelo JS, Saldarriaga W, Isaza C, Aiello H, et al. Clusters of sirenomelia in South America. Birth Defects Res A Clin Mol Teratol 2009;85(2):1128.

9. Stocker JT, Heifetz SA. Sirenomelia. A morphological study of 33 cases and review of the literature. Perspect Pediatr Pathol 1987;10:750.

10. Sirtori M, Ghidini A, Romero R, Hobbins JC Prenatal diagnosis of sirenomelia. J Ultrasound Med 1989;8(2):83-8.

11. Davari Tanha F, Gogol N, Kaveh M. Sirenomelia (mermaid syndrome) in an infant of a diabetic mother. Acta Medica Iranica 2003;41(1):69-72.

12. Pinette MG, Hand M, Hunt RC, Blackstone J, Wax JR, Cartin A. Surviving sirenomelia. J UItrasound Med 2005;24(11):1555-9.

13. Fadhlaoui A, Khrouf M, Gaigi S, Zhioua F, Chaker A. The sirenomelia sequence: a case history. Clin Med Insights Case Rep 2010;3:41-9.

14. Stanton MP, Penington EC, Hutson JM. A surviving infant with sirenomelia (Mermaid syndrome) associated with absent bladder. J Pediatr Surg 2003;38(8):1266-8. 